\title{
Productivity from the Viewpoint of Lighting Companies in Valencia
}

\author{
Sofia Estelles-Miguel ${ }^{1}$, Carlos Andrés Romano ${ }^{1}$, José Miguel Albarracin Guillem ${ }^{1} \&$ Marta Palmer Gato ${ }^{1}$ \\ ${ }^{1}$ Dpto Organización de Empresas, Universitat Politècnica de València, Spain \\ Correspondence: Sofia Estelles-Miguel, Dpto Organización de Empresas (Edificio 7D), Universitat Politècnica de \\ València, Camino de Vera SN, 46022 Valencia, Spain. Tel: 34-655-68-72-99.
}

Received: November 12, 2015

Accepted: December 1, 2015

Online Published: December 3, 2015

doi:10.5430/bmr.v4n4p43

URL: http://dx.doi.org/10.5430/bmr.v4n4p43

\begin{abstract}
In recent years, the lighting industry has abandoned the use of work measurement and standards time tools and everything the use of such tools implies. Seemingly, their use was considered politically incorrect, perhaps because of the way companies approached these tools in the past. Nevertheless, these tools are still useful for planning and managing productivity and are becoming increasingly necessary. By investigating lighting companies in the region of Valencia (Spain-Europe), this study analyses perceptions about productivity, work measurement and standards time and to explores how companies use these tools. A survey gathering responses from interviews with 42 lighting companies (of the 230 entrerprises) was used to collect data on these companies' perceptions. This is considered a representative sample, been the error margin of $14 \%$ whith a confidence level of $95 \%$. Data from these interviews were then analysed. This article presents results of this analysis.
\end{abstract}

Keywords: Productivity, Work measurement, Standards times, Lighting companies

\section{Introduction}

The importance of productivity is recognized internationally because changes in productivity can fundamentally affect a country's living standards in a large number of economic and social areas.

To compete, productivity is one of the most important aspects within a country's productive activities. This is the challenge faced by the worldwide production industry, but also by the services industry. If companies in these industries wish to remain in the market, quality and price are indispensable. This can be achieved by increasing productivity for which it is necessary to update and innovate technical production conditions and continually improve industries' value chains (Porter, 1999). It is fundamental to understand the importance of a country's productivity because productivity affects inflation, living standards, employment and so forth (Sumanth, 1999).

Productivity generally expresses the relationship between the quantity of goods and services produced (output) and the quantity of labour, capital, land, energy and other resources to produce it (input). When measured, productivity is often viewed as a relationship between output and a single measure of input such as capital. When there are multiple input measures or indices, the equation becomes complex and often requires subjective weightings. This is where the seemingly simple definition of output versus input becomes complex and confusing (Smith, 2001).

Currently, in the Spanish economy, there exists a situation of job destruction and an unprecedentedly high unemployment rate. Despite signs of recovery in productivity, Spain's progress in this area has been slow and static.

In this context, if the factors that affect productivity are measured and identified correctly, there will be a greater likelihood of success in analysing these factors, diagnosing the conditions of a company's productivity and, fundamentally, knowing which actions should be undertaken to improve productivity.

For all of the above reasons, we decided to analyse how companies themselves view productivity, how they measure productivity and how they think productivity affects their companies. The main objective of this paper is to analize the productivity of companies in this sector and the methodologies used to mesure it.

This paper is organized as follows, section 1 in which an introduction is presented to this article. In the section 2 an extensive literature review on the concept of productivity, since its first appearance in the literature in Quesnay (1776). Section 3 explained the method used for data collected. In section 4 the results obtained are presented and finally section 5 presented a discussion of the results and ultimately the conclusions of the paper. 


\section{Defining Productivity}

In an environment characterized by strong competition, technological change, globalization, market deregulation and fragmentation of demand, productivity has emerged as one of the main factors that contribute to determining competitiveness. Although the concept of productivity is widely discussed by politicians, economists, managers and the media, it is often vaguely defined and poorly understood. In practice, this lack of knowledge results in productivity being ignored by those who influence production processes (Tangen, 2002).

The concept of productivity has varied over time. We hereby present a summary of this evolution. The concept of productivity appeared for the first time in Quesnay's (1766) work. Later, Smith (1776) wrote, "The annual produce of the land and labour of any nation can be increased in its value by no other means, but by increasing either the number of its productive labourers, or the productive powers of those labourers who had before been employed. The advancement of productive faculties depends, above all, on the progress of the labourers' abilities and, in second place, on the progress in machinery with which they work...". In his magnum opus, Capital, Marx (1867) wrote that "The productive labour is determined by multiple circumstances, among others by the average worker's skill level, the state of development in science and its technological applications, social coordination of the production process, the scale and effectiveness of the means of production, the natural conditions". Littré (1883) defined productivity as "the faculty to produce". In the early 20th century, defined productivity as the relationship between production and the means employed to achieve that production (Summant, 1999).

Weintraub (1937) developed measures of work productivity in manufacturing companies. Siegel (1940) introduced the concept of unit cost of labour in the measure of productivity. Tinbergen (1940) defined productivity as "the ratio between real output and the use of real factors or inputs". In 1950, the Organisation for European Economic Co-operation (OEEC) defined productivity as the ratio obtained by dividing production by one of the factors of production (Summant, 1999). Others have talked of total productivity as an average that remains unaltered when each individual productivity remains unaltered (ILO, 1951). Later, Siegel (1953) referred to productivity as the relation between inputs and products associated with the productive activities, both measured in real terms. Davis (1955) defined productivity as the change in the product obtained from resources spent. Solow (1957) incorporated the "residual" in the measure of productivity. Fabricant (1959) defined productivity as the ratio between production and input. Denison (1962) introduced the quality of work carried out as part of the concept of productivity. Functional definitions have been made for partial productivity, total factor productivity and total productivity (Kendrick \& Creamer, 1965). They defined productivity as the technical aspect of exploitation of resources and claimed that its tendency decides a company's future (Klein, 1965). Farag (1967) included the input-output relationship in the measure of a company's productivity. According to Wolf (1969), "The concept of productivity is understood through the terms of function of production that specify the possibility to substitute between capital and work and other inputs". The International Labor Organization (1969) reported that productivity is the ratio between output and the total input or factors required to produce the output, referring to productivity as total factor productivity.

Correa (1970) measured productivity by dividing total production by the value of inputs used. Yoshihara et al. (1971) analysed the repercussions of changes in productivity in the price index. Elliot-Jones (1972) incorporated the input-output relationship in the measurement of companies' productivity. Hernández Laos (1973) defined productivity as the quantity of output obtained per unit of factor or factors used to achieve it, measured in physical terms. Siegel (1976) revised his earlier definitions, defining productivity as the relationship between the quantity of goods produced and the quantity of resources used in production and as a family of ratios between production and input. Mundel (1976) developed indices of productivity for companies, whereas Gold (1976) proposed the focus of financial ratios in the measurement of productivity, and Taylor and Devis (1977) proposed a model to measure total factor productivity. Hershaur and Ruch (1978) proposed a servosystem model for worker productivity and claimed that productivity relates input to output via a conversion process. Stewart (1978) defined productivity as the ratio of performance with respect to organizational targets among total input parameters and incorporated the concept of utility to measure manufacturing productivity. Agarwal (1979) proposed a compound index of productivity based on four financial ratios. Denison (1979) defined productivity as the efficiency of products through resources used, and Sumanth (1979) defined total productivity as the ratio of tangible production divided by tangible inputs.

An indirect form of measuring productivity is to determine and analyse "unit" costs (Adam et al., 1981). Productivity have also defined productivity as the outcome of the complex social process consisting of science, research and development, education, technology, business management, production methods and organizations of workers (Kurosawa, 1983). Novelo (1985) defined productivity as the human phenomenon determined by three factors and 
one outcome: the aptitudes and attitudes of man, the efforts invested in work, the evolution of the input-output relationship and the quality of the work and the labour. Prokopenko (1987) defined productivity as the relationship between the production yielded by a production or services system and the resources used to obtain this production. Mercado (1997) defined it as the final output of the effort and combination of all human, material and financial resources that make up the company.

Productivity generally expresses the relationship between the quantity of goods and services produced (output) and the quantity of labour, capital, land, energy and other resources to produced it (input) (Smith, 2001).

Productivity is the belief in human progress. It is a state of mind that aims at perpetual improvement. It is a ceaseless effort to apply new technology and new methods for the welfare and happiness of humankind (Asian Productivity Organization, 2007).

Productivity is an expression of how efficiently goods and services are being produced. Productivity is therefore expressed in physical or economic units, in quantities or in values (money) (Lucey, 2007).

Productivity is a process of continuous improvement in the production/supply of quality output/service through efficient, effective use of inputs, with emphasis on teamwork for the betterment of all (Trade Unionists, 2008).

Productivity is an attitude that seeks the continuous improvement of what exists. It is a conviction that one can do better today than yesterday, and that tomorrow will be better than today. Furthermore, it requires constant efforts to adapt economic activities to ever-changing conditions, and the application of new theories and new methods (European Productivity Agency, 2008).

Productivity is the ratio of output to input for a specific production situation. Rising productivity implies either more output is produced with the same amount of inputs, or that fewer inputs are required to produce the same level of output (Roger, 1998; Russell \& Taylor, 2009).

Productivity is the ratio of outputs to inputs. To improve this ratio, the organization must implement processes of continuous improvement (Chinda, 2010).

Productivity is a measure of manufacturing system or process output per unit of input, over a specific period, used as a metric of the production and the engineering efficiency (Makris et al., 2014).

The review of different definitions reveals that productivity consists of different variables such as people, technology, machinery and resources, all of which are employed to create goods and services that benefit all parties involved in the process.

Measurement of productivity is an excellent way to evaluate a company. Improving productivity is seen as a key issue for long-term survival and success.

\section{Method}

In the current study, 42 companies (from 230, being the error margin of 14\% with a confidence level of 95\%) from the lighting sector in the region of Valencia were visited and surveyed. The sample is considered representative.

Although identification data and contact data (e.g., company name, interviewee name, telephone number, e-mail, sector and product type) were collected to identify companies and to follow up if responses were incomplete or not fully understood, these data were treated confidentially.

Data on the companies' sector were useful to categorize questionnaires because the questionnaire was completed not only by lighting companies but also by companies in other productive sectors in the region of Valencia.

General questions (e.g., number of employees and turnover) were also asked to characterize the companies.

Surveys were completed via a range of media, including personal visits to the company, e-mail and via some associations that helped us conduct the survey.

\section{Results}

The sample comprised 42 lighting companies from the region of Valencia. Total number of employees in each company ranged between a minimum of 3 and a maximum of 150. The average company size was 36 employees, and the mode and median were both 20 . The number of direct workers or size of direct work force ranged between 2 and 100, with an average of 29 , a mode of 6 and a median of 20 .

Questions addressed how the company was structured and how important the company considered productivity and its measurement. 


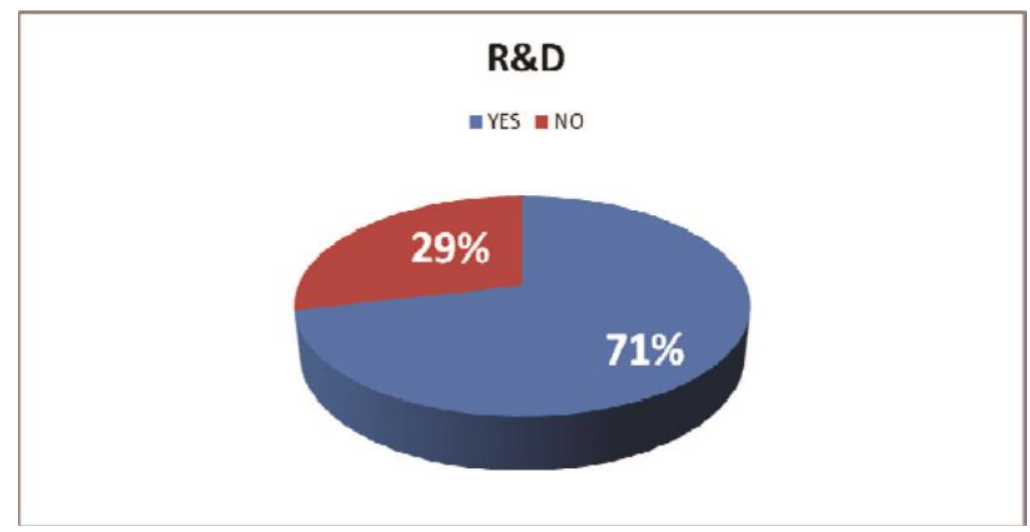

Figure 1. Does the company have an R\&D department? Source: Authors' own data.

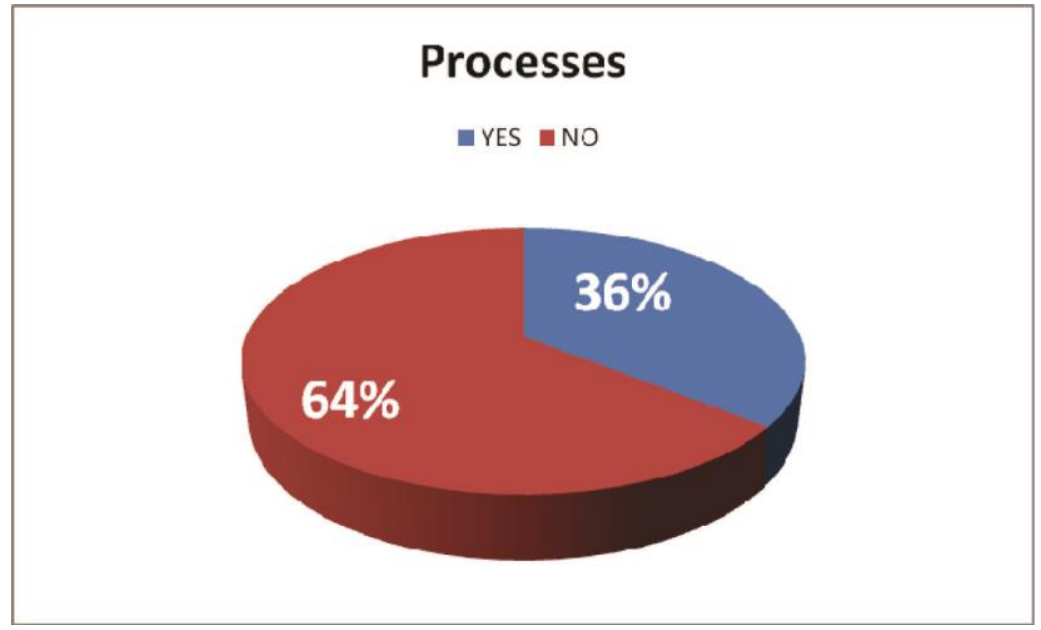

Figure 2. Does the company have a processes deparment? Source: Authors' own data.

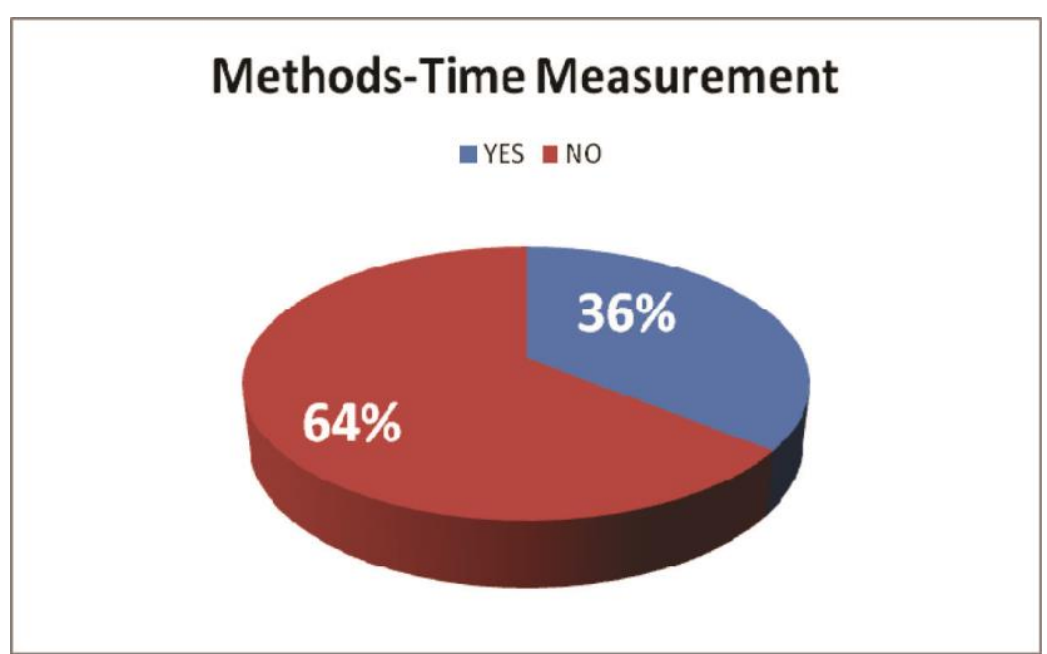

Figure 3. Does the company have a measurement and standard times deparment?.Source: Authors' own data.

As shown in Figures 1, 2 and 3, the majority of companies interviewed had Research and Development (R\&D) departments (71\%), although only $36 \%$ of companies had process departments or methods and measurement and standard times departments. As shown in Figure 4, however, the majority of companies considered that they should improve their productivity $(88 \%)$. 


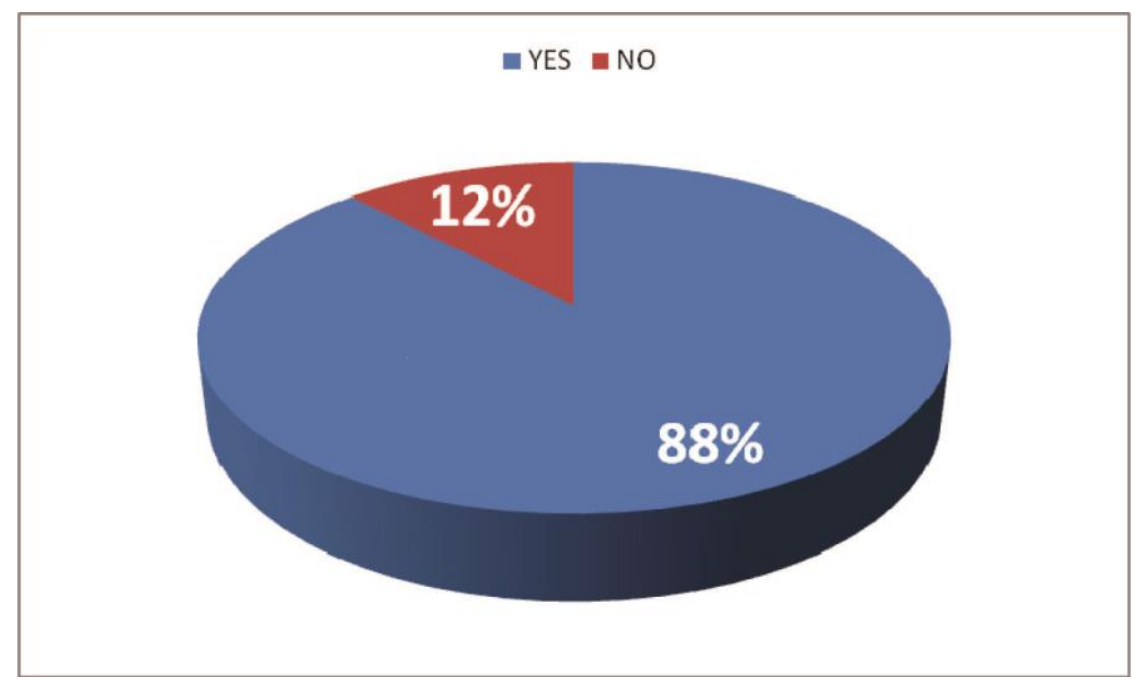

Figure 4. Do you think your company should improve its productivity?.Source: Authors' own data.

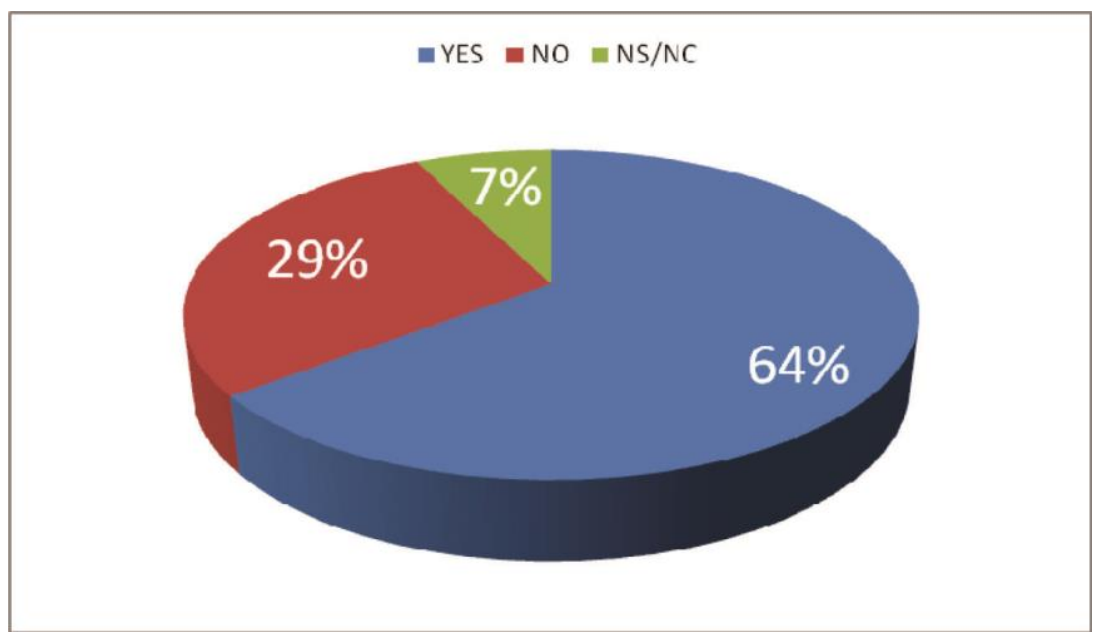

Figure 5. Does the company management believe that working methods and time management are useful to improve the compay's productivity?.Source: Authors' own data.

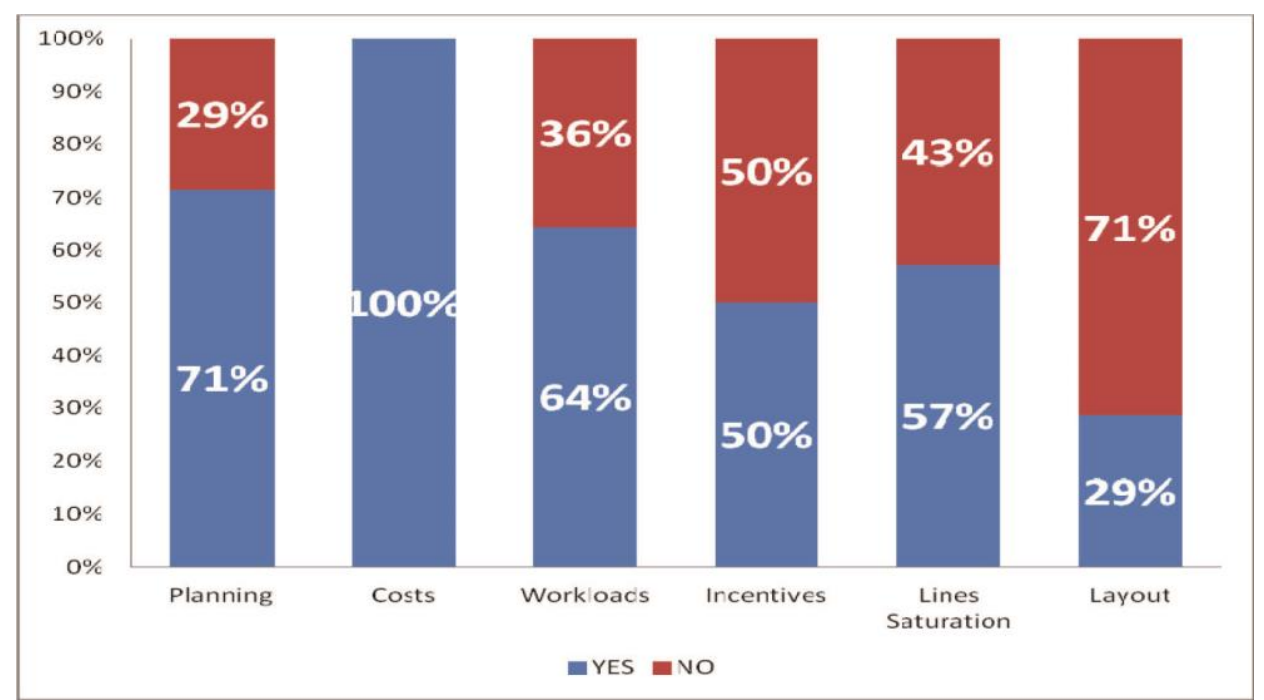

Figure 6. The management believes, that Times Measurement is useful for...Source: Authors' own data. 


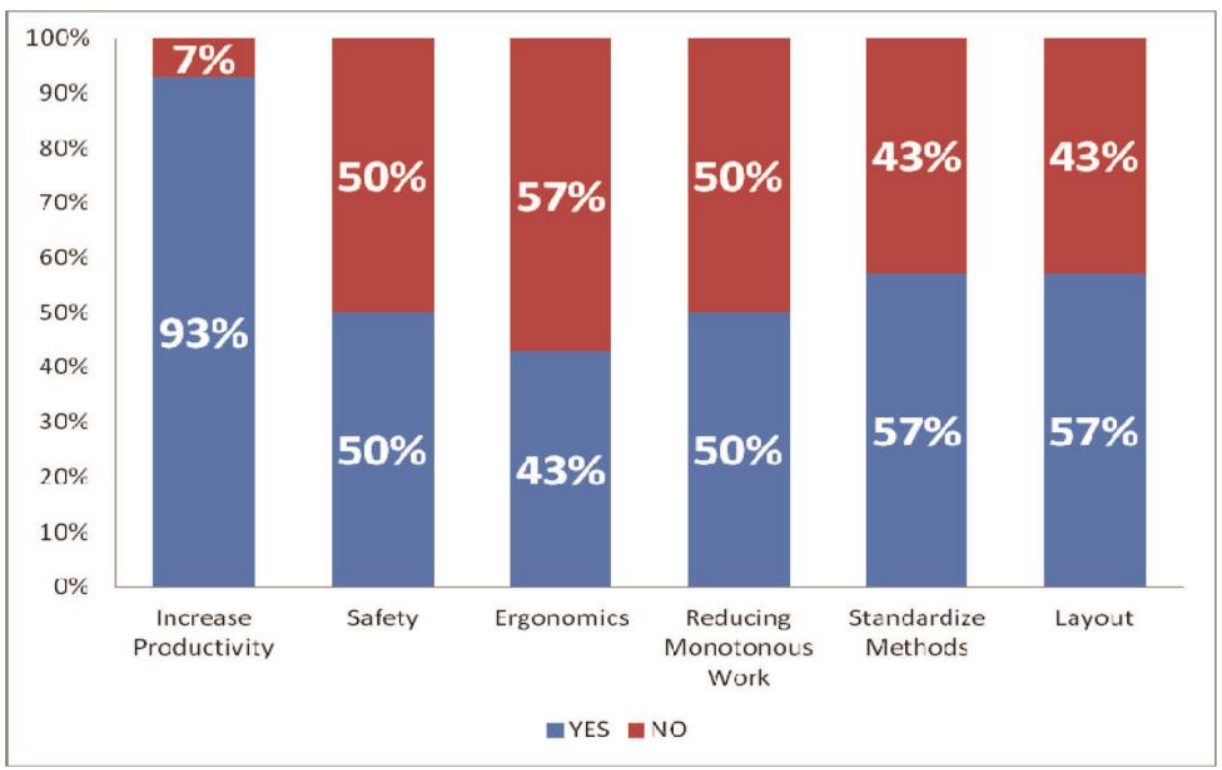

Figure 7. The management believes, that Working Mehods are useful for...Source: Authors' own data.

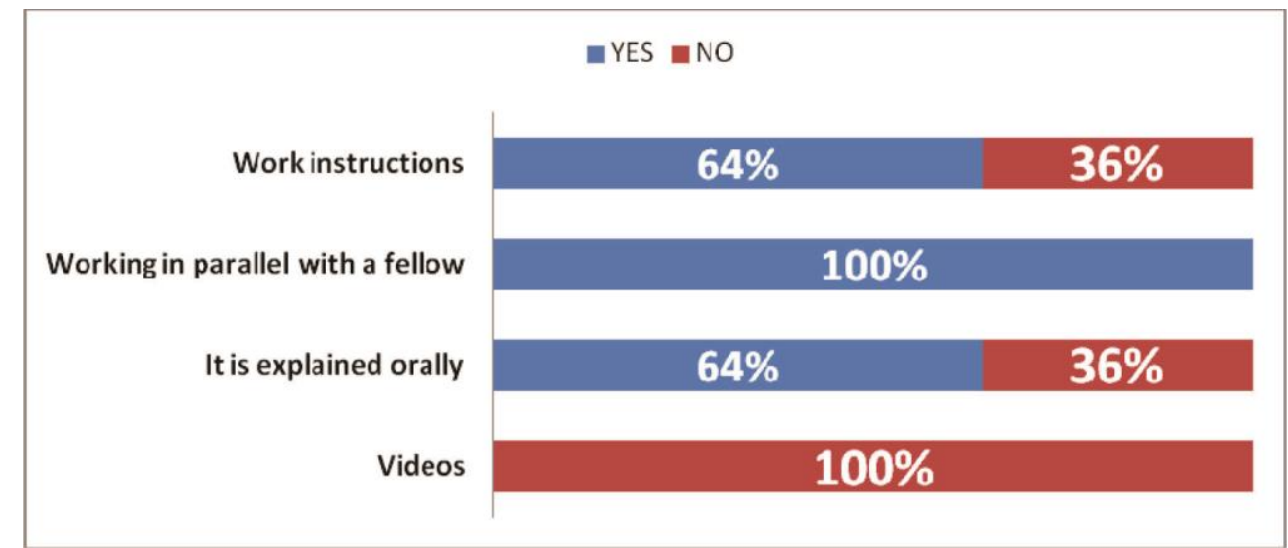

Figure 8. To train an operator in a new operation, what thecnique uses the company? Source: Authors' own data. 4.1 For those without time measurement system

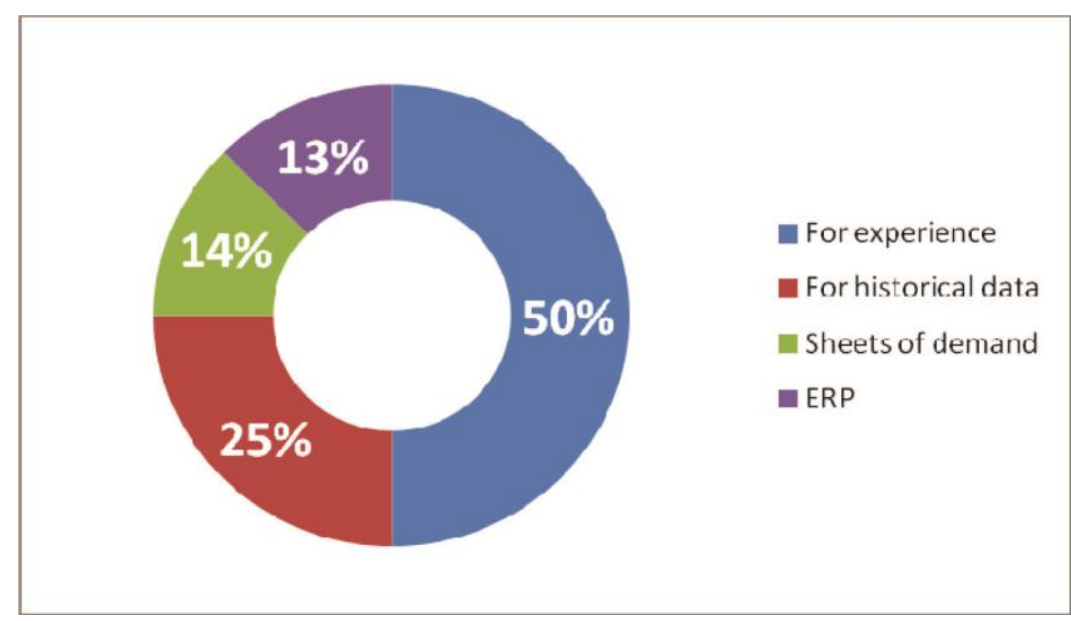

Figure 9. How the company does the planning? Source: Authors' own data. 


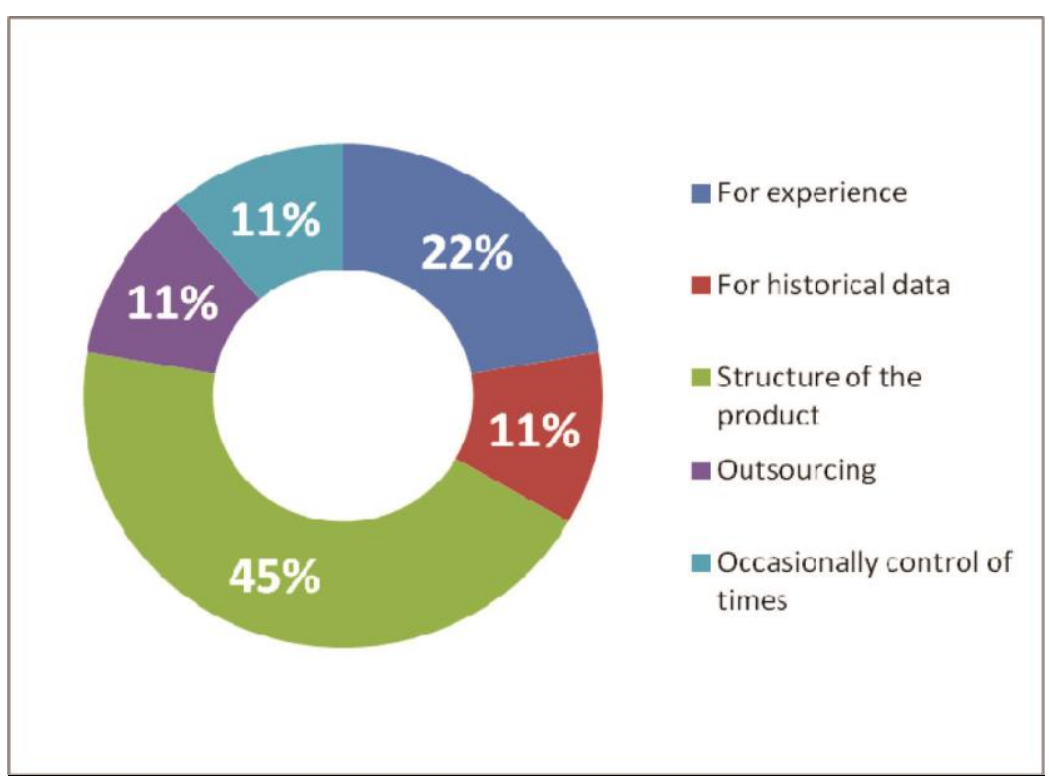

Figure 10. How the company calculates product costs? Source: Authors' own data.

\subsection{For those with time measurement system}

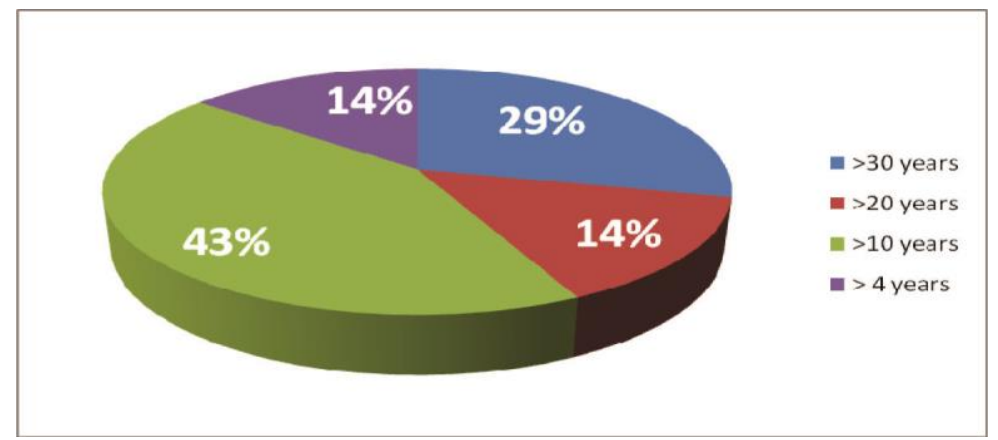

Figure 11. When the system was introduced in the company? Source: Authors' own data.

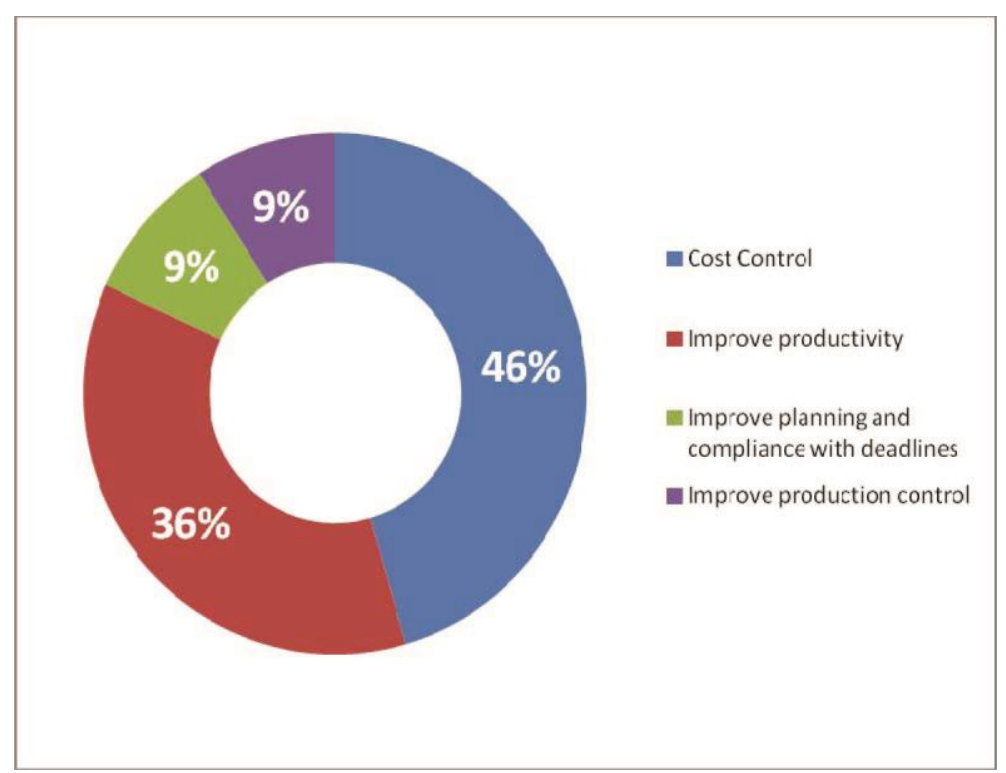

Figure 12. Why the system was introduced in the company? Source: Authors' own data. 


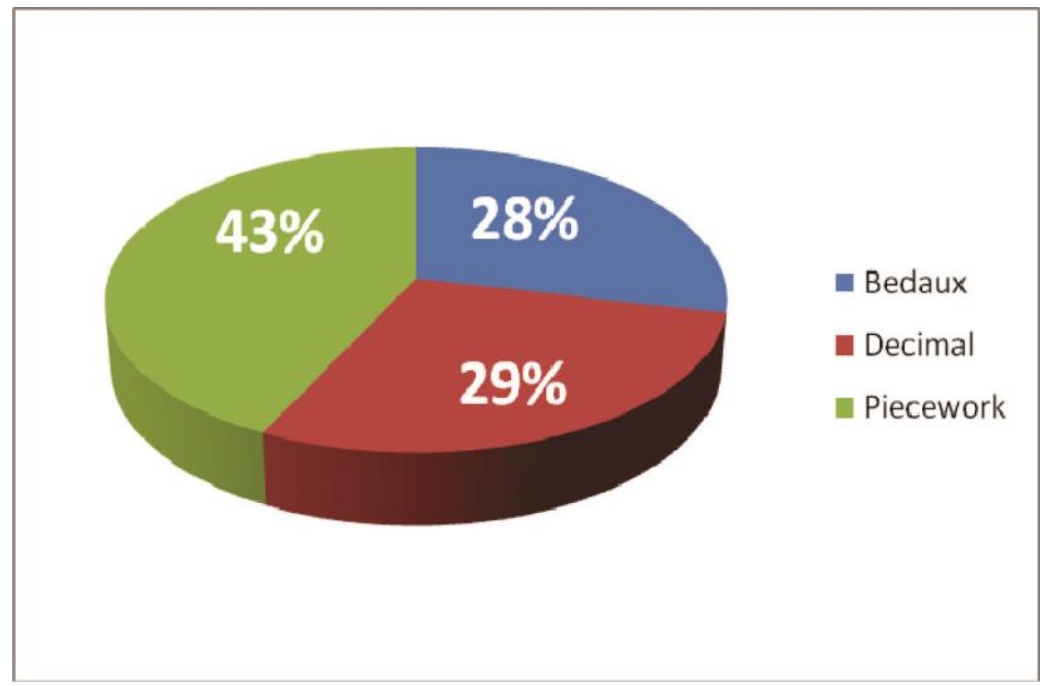

Figure 13. Measurement time system used. Source: Authors' own data.

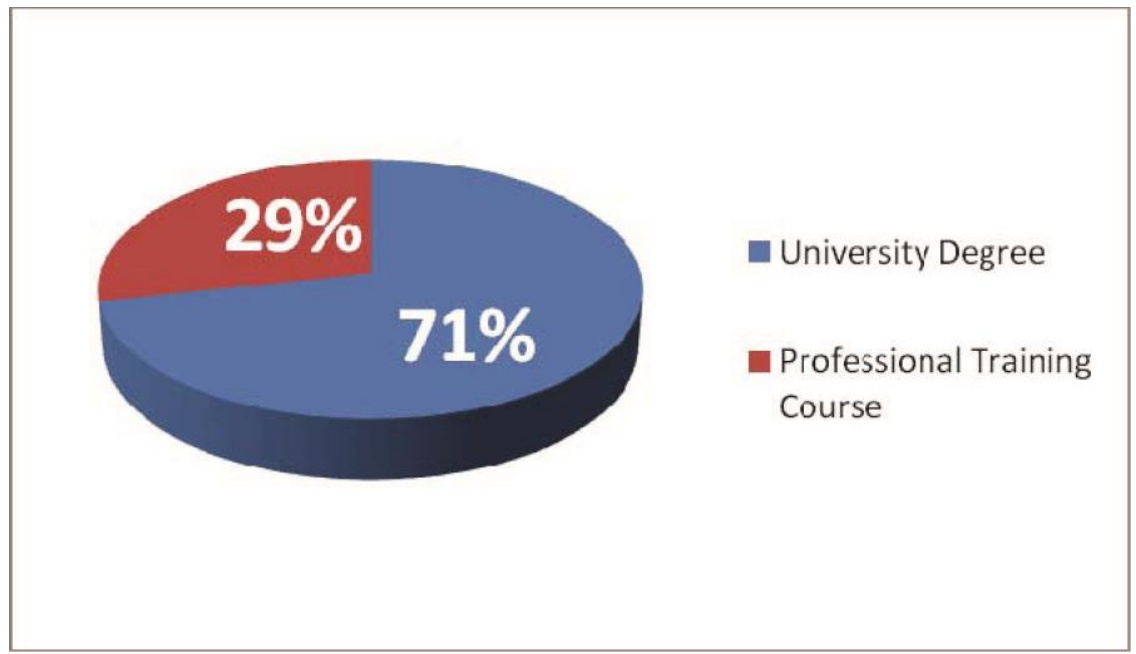

Figure 14. Which degree have the staff responsible to time measurement. Source: Authors' own data.

\section{Discussion and Conclusions}

From the analysis in this article, we can conclude that the definition of productivity has varied over time from its first appearance in 1766, and it has adapted to the times, while different meanings have been included in the definition of productivity or tools to measure productivity.

The participants of the survey neither gave a definition of productivity nor received a request to do so. Perhaps it would have been interesting to see how each company understood productivity and the distinctions that different companies may have included in the concept.

All companies interviewed felt that the time measurement is important for calculating cost, $71 \%$ for planning, $64 \%$ for calculating workloads, $57 \%$ to estimate saturation lines, and a half to calculate incentives and $29 \%$ for the layout, when you can use time measurement for all of them. In the other had the management believes that the working methods are useful overall for increasing productivivy (93\%), and almost a half believes for safety, ergonomics, reducing monotonous work, standardize methods and layout, when you can use working methods for all those functions. What it makes us think that they are still little-known tools in companies.

To train a new job to operators, no company uses videos, while all train them working in parallel with another operator, only $64 \%$ of companies have work instructions, it is a low percentage compared to other sectors.

Most of companies (85\%) having a time measurement system were introduced more than 10 years ago. Nearly half (46\%) as implemented to control cost, being the second reason improve productivity (36\%). 
As for the measurement time systems used $43 \%$ use the piecework, while the rest is divided between Bedaux and decimal system. Regarding the incentive systems, $57 \%$ of the companies interviewed have and the rest did not. Of those with incentive systems $43 \%$ have implemented it in all sections.

Participating companies understood that productivity is important for their company and for maintaining the company in the market. In fact, $88 \%$ of companies reported that they should improve their productivity, and $64 \%$ of companies understood that methods and time management are useful tools to achieve better productivity. Nevertheless, the majority of companies had a design department, whereas only $36 \%$ had a methods and time-management department or, in its absence, a processes department, which often performs the job of assigning a time to each task.

The authors of the present study consider productivity fundamental for both companies and countries. Nevertheless, the majority of companies fail to attribute the importance they should to productivity, and when they reflect upon this fact, they realize but they should place a greater priority on productivity. Methods and time management are not only tools to improve productivity, but also to plan, to calculate costs of outputs, workloads and overburdening within the company, to improve job security, to analyse job ergonomics, and to perform a host of other important tasks.

Also, as a future line of research, should conduct more studies on productivity in others sectors, looking at once if there is a pattern in it that can be extrapolated in some cases. Indicate that we have begun to realize them in the ceramics sector, in the furniture industry, in the metalworking sector at Valencia and finally we have extended the current study of the manufacturers of luminaires to companies throughout Spain sector.

\section{Acknowledgments}

The authors thank the Laboratorio de Luminarias de AIMME (Instituto Tecnológico Metalmecánico) and especially his Director, Juan José González, for helping with the data collection for the survey.

\section{References}

Adam, E.E., Hershauer, J.C. \& Ruch, W.A. (1981). Productivity and Quality Measurement as a Basis for Improvement. Englewood Cliffs, N.J. Prentice-Hall.

Agarwal, N.C. (1979). Research Notes: On the Interchangeability of Size Measures. Academy of Management Journal, 22 (2), pp. 404-409. http://dx.doi.org/10.2307/255598

Asian Productivity Organization (2007). Productivity Measurement. APO News, Tokyo, Japon. 37 (5), pp. 1-8.

Chinda, T. (2010). Structural Equation Modelling of Productivity Enhancement. Journal of Science Technology. 17 (3), pp. 259-276.

Correa, H. (1970). Economía de los Recursos Humanos. Fondo de Cultura Económica. México.

Davis, H.S. (1955). Productivity Accounting. University of Pennsylvania. The Wharton School. Industrial Research Unit. pp.132.

Denison, E.F.(1962). The sources of economic growth in the U.S. and the alternatives before us, Supplementary Paper $\mathrm{N}^{\mathrm{o}} 13$. New York: Committee for Economic Development.

Denison, E.F. (1979). Explanations of Declining Productivity growth. №354. The Brookings Institution.

Elliott-Jones, M.F. (1972). Inflation and Shelter in New York City. American Journal of Economics and Sociology. 31(1), pp. 1-7. http://dx.doi.org/10.1111/j.1536-7150.1972.tb03137.x

European Productivity Agency. (2008). Definition of Productivity. Available from http://www.npccmauritius.com/definition/. Accessed date: Sept 16, 2014.

Fabricant, S. (1959). Basic Facts on productivity change. New York: Columbia University Press, NBER.

Farag, S.M. (1967) Input-Output Analysis: Applications to Business and Accounting (Urbana: Center for International Education and Reseach in Accounting).

Gold, B. (1976). A Framework for Productivity Analysis. Applied Productivity Analysis for Industry, Oxford/New York/Toronto.

Hernández Laos, E. (1973). Evolución de la productividad de los factores en México. Ediciones Productividad. México.

Hershauer, J.C. \& Ruch, W.A. (1978). A Worker Productivity Model and its Use at Lincoln Electric. Interfaces. 8 (3), pp. 80-90. http://dx.doi.org/10.1287/inte.8.3.80 
International Labor Organization (ILO) (1969). "Measuring productivity" Studies and Report New Series $\mathrm{N}^{\circ} 75$, Geneva.

Kendrick, J.W. \& Creamer, D. (1965). Measuring Company Productivity, National Industrial Conference Board Inc., New York.

Klein, L.R. (1965). Analysis of Inflaction. National Bureau of Economic Research, pp. 35-66.

Kurosawa, K. (1983). Medición y Análisis de la Productividad a Nivel de Empresa YRGOY; Venezuela.

Littré, E. (1883). Dictionnaire de la Langue Française Contenant... la Nomenclature... la Grammaire... la Signification des Mots... la Partie Historique... l'Etymologie, Hachette \& Cie, Paris.

Lucey, J. (2007). Productivity: What's going on in Europe part II. Management Services, 51 (2), pp. 32.

ILO (1951). Record of Proceedings. International Labour Conference. 34th Session Appendix VIII. Geneva. http://labordoc.ilo.org/record/442515.

Quesnay, F. (1766). Analyse de la formule arithmétique du tableau économique de la distribution des dépenses annuelles d'une nation agricole, Journal de l'Agriculture, du Commerce \& des Finances, pp. 11-41.

Makris, S., Papakostas, N. and Chryssolouris, G. (2014) Productivity. CIRP Encyclopedia of Production Engineering, pp. 1006-1007. http://dx.doi.org/10.1007/978-3-642-20617-7_6570

Marx, K. (1867) Capital. Tomo 1 Volume 2. Chapter XV. New York: Penguien Books. Reedited 1976.

Mercado, E. (1997). Productividad, base de la Competitividad. LIMUSA. Noriega Editores, México.

Mundel, M.E. (1976). Measures of productivity. Industrial Engineering, 8(5), pp 24-26.

Novelo, V. (1985). Roxborough, Ian. Unions and politics in Mexico: the case of the automobile industry. Cambridge University Pres, 207p. (Latin American Studies; Nº).

Porter, M. (1999). Ser competitivos. Nuevas aportaciones y conclusions. Deusto. Bilbao.

Prokopenko, J. (1987). Productivity Management: A practical handbook. International Labour Organization.

Roger, M. (1998). The Definition and Measurement of Productivity. Melbourne Institute Working Paper No 9/98. Melbourne Institute of Applied Economic and Social Research, the University of Melbourne, Australia.

Russell, R.S. \& Taylor, III, B.W. (2009). Operations Management along the Supply Chain. 6 th ed. John Wiley and Sons, Hoboken, N.J. USA.

Siegel, I.H. (1940). Hourly earnings and unit labor cost in manufacturing. Journal of the American Statistical Association, 35 (211) pp. 455-460. http://dx.doi.org/10.1080/01621459.1940.10501730

Siegel, I.H. (1953). Technological Change and Long-Run Forecasting. Journal of Business of the University of Chicago, 26 (3), pp. 141-156. http://dx.doi.org/10.1086/233111

Siegel I.H. (1976). Measurement of Company Productivity. National Center for Productivity and Quality of Working Life, pp. 15-26.

Smith, A. (1776). An Inquiry into the Nature and Causes of the Wealth of Nations. New York: Oxford University Press. Reedited: 1976. http://dx.doi.org/10.1093/oseo/instance.00043218

Smith, K.E. (2001) Chapter 2.1. The concept and importance of productivity. Maynard's. Industrial Engineering Hand Book.

Solow, R. (1957). Technical Change and the Aggregate Production Function. Review of Economics and Statistics 39, pp. 312-320. http://dx.doi.org/10.2307/1926047

Stewart, W.T. (1978). Yardstick for Measuring Productivity. Industrial Engineering, 10 (2), pp. 34-37.

Summant, D. (1979). Productivity Measurement and Evaluation Models for Manufacturing Companies. (Doctoral dissertation, Illinois Institute of Technology).

Summant, D. (1999). Administración para la productividad total: Un enfoque sistémico y cuantitativo para competir en calidad, precio y tiempo. Compañía Editorial. Continental (México).

Tangen, S. (2002). Understanding the Concept of Productivity. Proceeding of the 7th Asia Pacific Industrial Engineering and Management Systems Conference (APIEMS2002), Taipei. 
Taylor, B.W. \& Davis, K.R. (1977). Corporate Productivity-Getting it all Together. Industrial Engineering, 9 (3), pp. 32-36.

Timbergen, J. (1940). Econometric business cycle research, Review of Economic Studies 7, 73-90. http://dx.doi.org/10.2307/2967472

Trade Unionists (2008). Deinition of Productivity by Trade Unionists. Available from http://www.npccmauritius.com/tudef/. Accessed date: Sept 17, 2014.

Weintraub, D. (1937). Uneployment and increasing productivity, National Resources Committee (ed): Technological trends and national policy. Washinton, D.C. pp. 23-47.

Wolf, C. (1969), Management, Productivity and Growth. Santa Mónica, CA. RAND. http://www.rand.org/pubs/papers/P4244.

Yoshihara, K., Furuya, K. \& Suzuki, T. (1971). The Problem of Accounting for Productivity Change in the Construction Price Index. Journal of the American Statistical Association, 66 (333) pp.33-41. http://dx.doi.org/10.1080/01621459.1971.10482214 